Volume 1 Nomor 2 Edisi Desember 2013
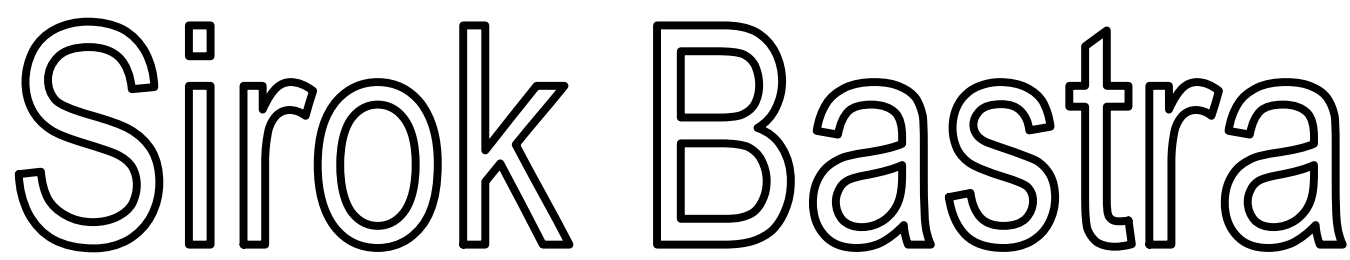

J URNAL ILMIAH KEBAHASAAN DAN KESASTRAAN

\begin{tabular}{|c|c|c|c|c|c|}
\hline $\begin{array}{c}\text { Sirok Bastra } \\
\text { Jurnal Kebahasaan dan } \\
\text { Kesastraan }\end{array}$ & Volume 1 & Nomor 2 & $\begin{array}{c}\text { Hlm. } \\
123-249\end{array}$ & $\begin{array}{c}\text { Pangkalpinang, } \\
\text { Desember } \\
2013\end{array}$ & $\begin{array}{c}\text { ISSN } \\
2354-7200\end{array}$ \\
\hline
\end{tabular}

KANTOR BAHASA KEPULAUAN BANGKA BELITUNG 

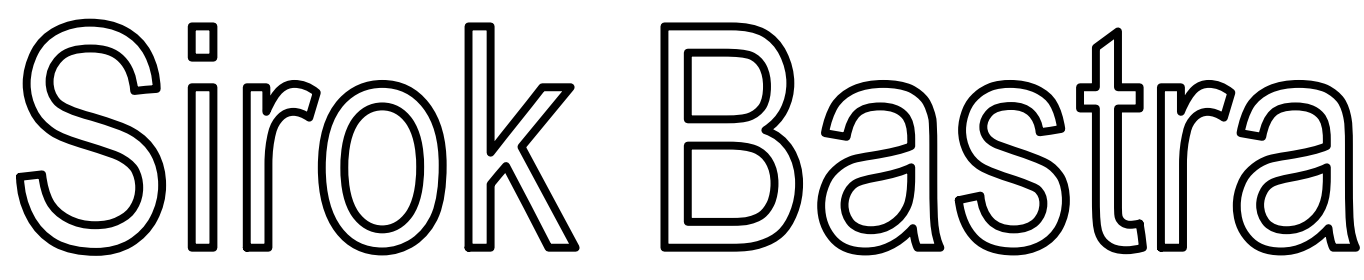

\section{J URNAL ILMIAH KEBAHASAAN DAN KESASTRAAN}

Jurnal ini merupakan wadah informasi mengenai kebahasan, kesastraan, dan pengajarannya yang memuat hasil penelitian, studi kepustakaan, dan tulisan ilmiah bidang kebahasan, kesastraan, dan pengajarannya. Jurnal ini terbit dua kali setahun, yakni Juni dan Desember, serta terbit sejak Juni 2013.

\section{Penanggung Jawab}

Kepala Kantor Bahasa Provinsi Bangka Belitung

Drs. Umar Solikhan, M.Hum.

\section{Mitra Bestari}

Prof. Dr. Agus Nuryatin, M.Hum. (Bidang Bahasa dan Pengajarannya)

Prof. Amrin Saragih, Ph.D., M.A. (Bidang Sastra dan Pengajarannya)

Dr. Felicia Nuradi Utorodewo, M.Hum. (Bidang Bahasa dan Pengajarannya)

Dr. Pujiharto, M.Hum. (Bidang Sastra dan Pengajarannya)

\section{Pemimpin Redaksi}

Rahmat Muhidin, S.S.

\section{Penyunting}

Prima Hariyanto, S.Hum.

\section{Perancang Sampul}

Feri Pristiawan, S.S.

\section{Kesekretariatan}

Khaliffitriansyah, S.Pd. Dea Letriana Cesaria, S.Hum.

Lia Aprilina, S.Pd.

Andrian Priyatno, A.Md.

Elzam

\section{Alamat Redaksi dan Penerbit}

Kantor Bahasa Provinsi Bangka Belitung

Ruko Permata 7, Jalan Solihin G.P. Km 4, Pangkalpinang, Kep. Bangka Belitung

Telp./Faks.: 0717-438455, Pos-el: sirokbastra@gmail.com

Pemuatan suatu tulisan dalam jurnal ini tidak berarti redaksi menyetujui isi tulisan tersebut. Isi tulisan menjadi tanggung jawab penulis. Tulisan telah ditinjau oleh mitra bestari. Setiap karangan dalam jurnal ini dapat diperbanyak setelah mendapat izin tertulis dari penulis, redaksi, dan penerbit. 


\section{KATA PENGANTAR}

Puji syukur ke hadirat Pemilik dan Pencipta semesta ini yang memiliki kuasa atas diri-Nya sendiri. Dialah Tuhan Yang Maha Esa yang telah memberikan rahmat dan hidayah-Nya sehingga Volume 1 Nomor 2 Jurnal Sirok Bastra dapat terbit tepat pada waktunya.

Pada nomor kedua ini, dimuat sebelas tulisan, yakni enam tulisan kebahasaan, empat kesastraan, dan satu pengajaran sastra. Dari segi bahasa, sebagian besar tulisan disajikan dalam bahasa Indonesia, hanya dua tulisan yang disajikan dalam bahasa Inggris. Kami mengucapkan terima kasih kepada para penulis yang telah bersedia menerbitkan karya mereka pada edisi ini. Para penulis merupakan para peneliti, pakar, dosen, dan mahasiswa dari berbagai perguruan tinggi dan instansi. Terima kasih juga kami sampaikan kepada para mitra bestari kami yang telah memberi ulasan terhadap tulisan-tulisan yang masuk ke redaksi.

Demi memenuhi keberagaman isi dan penulis, Sirok Bastra membuka kesempatan bagi para peneliti dan penulis menyampaikan hasil penelitian dan pemikiran mutakhir dalam bidang kebahasaan, kesastraan, dan pengajarannya.

Pangkalpinang, Desember 2013

Tim Redaksi 


\section{UCAPAN TERIMA KASIH UNTUK MITRA BESTARI}

Redaksi Sirok Bastra mengucapkan terima kasih kepada para mitra bestari yang telah meninjau, menimbang, dan mengulas makalah-makalah yang diterbitkan dalam Sirok Bastra Volume 1 Nomor 2, edisi Desember 2013, yakni

Prof. Dr. Agus Nuryatin, M.Hum.

Bidang Sastra dan Pengajarannya

Universitas Negeri Semarang

Semarang, Jawa Tengah

Prof. Amrin Saragih, Ph.D., M.A.

Bidang Bahasa dan Pengajarannya

Universitas Negeri Medan

Medan, Sumatra Utara

Dr. Felicia Nuradi Utorodewo, M.Hum.

Bidang Bahasa dan Pengajarannya

Universitas Indonesia

Depok, Jawa Barat

\section{Dr. Pujiharto, M.Hum.}

Bidang Sastra dan Pengajarannya

Universitas Gadjah Mada

Yogyakarta, Daerah Istimewa Yogyakarta 


\section{DAFTAR ISI}

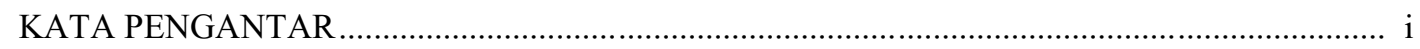

UCAPAN TERIMA KASIH UNTUK MITRA BESTARI .................................................... ii

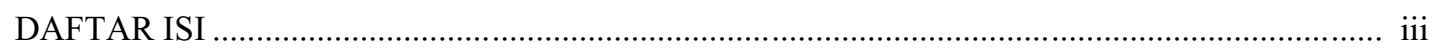

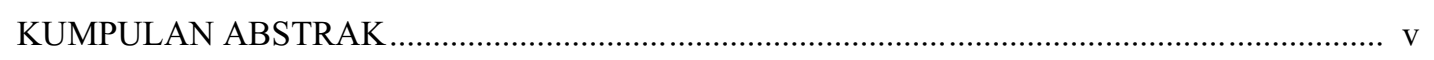

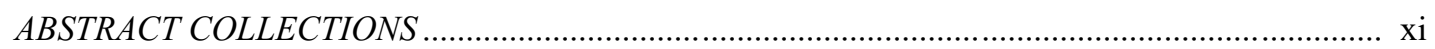

BAHASA INDONESIA DALAM INFORMASI DAN IKLAN DI RUANG PUBLIK KOTA PANGKALPINANG

(Indonesian in Information and Advertising in Public Space Pangkalpinang)

Umar Solikhan $123-129$

PERBEDAAN MAKNA NOMINA BERAFIKS $P E-, P E R-, P E--A N$, DAN $P E R--A N$ DALAM NASKAH HIKAYAT BAYAN BUDIMAN, HIKAYAT MUHAMMAD HANAFIYYAH, DAN HIKAYAT RAJA PASAI

(Affixed Noun Meaning Differences of pe-, per-, pe--an, and per--an in The Hikayat Bayan Budiman, Hikayat Muhammad Hanafiyyah, and Hikayat Raja Pasai Manuscripts)

Rindias H. Fatmasari $131-147$

WACANA RUBRIK INTIMATE DI MAJALAH DIGITAL INTERAKTIF MALE

(Intimate Rubric in Male Digital Interactive Magazine Discourse)

Prima Hariyanto $149-160$

AN ACOUSTICAL CONTRASTIVE ANALYSIS OF SUNDANESE CENTRAL VOWELS (Analisis Konstrastif Akustik Vokal Pusat Bahasa Sunda)

Yusup Irawan. $161-175$

KATA SUDAH SEBAGAI PENANDA ASPEK DENGAN AWALAN TER-

The Word of Sudah as An Aspect with Prefix Ter-

Dea Letriana Cesaria $177-182$

PERUBAHAN DAN PERGESERAN MAKNA DALAM KATA-KATA BERDERIVASI NOMINA KE VERBA YANG MENGANDUNG AFIKS $M E(N)-, M E(N)-K A N$, DAN $M E(N)-I$ PADA SURAT KABAR HARIAN KOMPAS

(Change and Shift of Meaning in The Derivated Words Nomine to Verb That Contain Affixes $m e(N)-$, me(N)-kan, dan me(N)- $i$ in The Kompas The Daily Newspaper)

Teodora Nirmala Fau $183-193$

MENCIPTA-KREATIF NASKAH DRAMA DENGAN STRATEGI MENULIS TERBIMBING (Creative Writing of Playscript eith Guided Writing Strategy)

Sony Sukmawan. $195-205$ 
PENGARUH KONSEP HAGABEON, HAMORAON, DAN HASANGAPON TERHADAP

KETIDAKSETARAAN GENDER DALAM AMANG PARSINUAN

(The Influence of Hagabeon, Hamoraon, and Hasangapon Concept for Gender Inequality in Amang Parsinuan)

Fransiska Simangunsong $207-220$

PERSPEKTIF PENGARANG MENGENAI RELASI ANTARA MANUSIA DAN

LINGKUNGAN HIDUP DALAM NOVEL PARTIKEL KARYA DEWI LESTARI: SEBUAH KAJIAN EKOKRITISISME

(Author's Perspective on The Relationship Between Humans and The Environment in The Novel Partikel Written by Dewi Lestari: an Ecocriticism Studies)

Alfi Yusrina Ramadhani $221-229$

FENOMENA HUKUM ADAT BALI TERHADAP BAYI KEMBAR BUNCING DALAM

NOVEL INCEST KARYA I WAYAN ARTIKA

Bali Custom Law Phenomenon of Kembar Buncing Infant in I Wayan Artika Novel Incest Annisa Aprinandri Irwin dan Khansa Khairunnisa $231-241$

RELIGIOUS AND MORAL VALUES IN MADURA FOLKTALES

Religiositas dan Nilai Moral dalam Cerita-Cerita Rakyat Madura

Imron Wakhid Harits. $243-249$ 
Alfi Yusrina Ramadhani: Perspektif Pengarang Mengenai Relasi ...

\title{
PERSPEKTIF PENGARANG MENGENAI RELASI ANTARA MANUSIA DAN LINGKUNGAN HIDUP DALAM NOVEL PARTIKEL KARYA DEWI LESTARI: SEBUAH KAJIAN EKOKRITISISME
}

\section{Author's Perspective on The Relationship Between Humans and The Environment in The Novel Partikel Written by Dewi Lestari: an Ecocriticism Studies}

\author{
Alfi Yusrina Ramadhani \\ Fakultas Ilmu Pengetahuan Budaya, Universitas Indonesia \\ Kampus Baru UI Depok, Jawa Barat, 16424 \\ pos-el: alfi.yusrina@hotmail.com
}

(diterima 28 Februari 2013, disetujui 30 September 2013, revisi terakhir 5 Oktober 2013)

\begin{abstract}
Abstrak
Krisis lingkungan terjadi karena ulah manusia. Manusia sering kurang memahami alam dan memiliki kesulitan untuk menciptakan sebuah relasi yang baik dengan lingkungan hidup. Penelitian ini mengurai perspektif pengarang tentang relasi antara manusia dan lingkungan hidup dalam novel Partikel karya Dewi Lestari. Pendekatan yang digunakan adalah pendekatan mimetik (tiruan), ekspresi (pengarang), dan obyektif (intrinsik). Metode yang digunakan dalam penelitian ini adalah metode deskriptif-analitik. Hal pertama yang dilakukan penulis dalam memberikan paparan deskriptif mengenai konsep-konsep pengarang tentang lingkungan hidup. Kemudian, penulis menganalisis unsur-unsur struktur naratif Partikel dengan pendekatan ekokritis. Hasil kesimpulan skripsi ini adalah novel Partikel mengandung sebuah gagasan utama bahwa pada hakikatnya manusia dan alam adalah satu. Gagasan utama tersebut merupakan perpanjangan dari perspektif pengarang dalam memandang hubungan manusia dengan lingkungannya.
\end{abstract}

Kata kunci: alam, Dewi Lestari, ekokritisisme, lingkungan hidup, novel

\begin{abstract}
The environmental crisis is caused by human activities. A lack of understanding between human and nature gives us trouble to create a good relationship with the environment. This study considers the aspect of the relationship between human and environment in the novel Partikel written by Dewi Lestari. I use mimetic, expressive and objective approaches. The method in this research is the descriptive-analytic method. First I provide an explanation of the environmental concepts the author provides. Then, I analyze the narrative structure of Partikel with the ecocritical approach. The conclusion of this paper is that the novel Partikel contains a main idea that in essence human and nature are one. The story in Partikel is based on the author's perspective from the sitation of the relationship between human and environment nowadays.
\end{abstract}

Key words: ecocriticism, ecological literature, environment, nature, novel

\section{PENDAHULUAN}

\subsection{Latar Belakang}

Bumi akan selalu mengalami perubahan. Setiap pertumbuhan dan perkembangan di kehidupan ini pasti selalu membawa perubahan terhadap bumi. Kenaikan jumlah populasi manusia yang melebihi kapasitas normal dan kemajuan teknologi yang begitu cepat telah menyumbangkan berbagai dampak tak terduga terhadap bumi ini.

Krisis lingkungan adalah masalah yang pelik. Planet bumi terus mengalami transformasi dari waktu ke waktu. Setiap hari proses itu terjadi semakin cepat.
Al Gore, seorang aktivis Amerika yang gigih menyuarakan keprihatinan terhadap pemanasan global, menyebut situasi seperti ini dengan new period of hyper-change. Sebutan tersebut bertitik tolak dari sebuah premis bahwa kita hidup pada zaman yang berubah sangat cepat dan mendalam (Basuki, 2013:66). Kekacauan radikal dalam hubungan manusia dengan ekosistem semesta adalah alasan yang paling fundamental dari perubahan global. Hal tersebut muncul karena ada pandangan dunia yang berwatak Cartesian-Newtonian-meletakkan manusia dalam posisi mendominasi alam-dan inilah yang 
menimbulkan kekacauan radikal.

Di bidang sastra, situasi bumi yang sedang sekarat menginspirasi beberapa pengarang Indonesia untuk menulis karya-karya yang mengangkat isu-isu lingkungan. Salah satunya adalah novel Partikel (2012) karya Dewi Lestari. Novel yang langsung dicetak 40.000 eksemplar ini karena terpicu dengan keadaan bumi saat ini yang sungguh menyedihkan. Ia pernah membaca sebuah buku yang membicarakan ekologi. Judul buku tersebut The Coming Global Superstorm (1999) karya Art Bell dan Strieber. Buku itu menginspirasi dibuatnya film The Day After Tomorrow (2004). Di buku tersebut, ada dugaandugaan kemungkinan dari bencana pemanasan global. Bukti-bukti tersebut telah sangat nyata untuk diacuhkan (Junaidi, 2006).

Dengan tidak meninggalkan kesetiaannya pada tema-tema sebelumnya, pada episode keempat ini Dewi Lestari tampak memberi porsi lebih besar untuk membicarakan masalah kesadaran berlingkungan hidup.

Sebagai seorang pengarang, kepiawaian Dewi Lestari sudah terbukti oleh berbagai penghargaan sastra yang telah diraihnya. Dewi Lestari dapat dikategorikan sebagai sastrawan Angkatan 2000. Berdasarkan ciri-ciri Angkatan 2000 yang dirumuskan Rampan (2000:liii), penulis menempatkan Dewi Lestari sebagai sastrawan Angkatan 2000 karena karya-karyanya mencirikan teknik-teknik khas sehingga mampu melahirkan wawasan estetik baru.

Partikel menonjolkan permasalahan relasi manusia dengan lingkungan hidup. Konsep lingkungan hidup dalam penelitian ini mencakup segala sesuatu di alam semesta, seperti hutan, sungai, orangutan, dan hewan liar. Isu lingkungan yang dideskripsikan dalam novel Partikel sangat dekat dengan situasi krisis lingkungan abad ini.

Tokoh utama dalam novel tersebut bernama Zarah. Tokoh protagonis tersebut digambarkan di dalam novel sebagai seorang fotografer berbakat. Sejak masa kecilnya, ia sudah peka dengan masalah lingkungan hidup. Kepekaan tersebut melatih Zarah untuk menangkap objek-objek alam melalui lensa kameranya. Perjalanan hidup Zarah selalu berdekatan dengan alam. Kisah petualangan Zarah di Batu Luhur, Kalimantan, Kenya, dan London mengasah pemikirannya tentang masalah lingkungan hidup.
Oleh karena itu, hipotesis penelitian ini adalah kritikkritik atas perilaku manusia terhadap lingkungan hidupnya di dalam Partikel yang merupakan hasil pengamatan pengarang dari situasi lingkungan hidupnya.

\subsection{Masalah}

Berdasarkan hipotesis tersebut, muncul beberapa permasalahan yang dibahas dalam penelitian ini seperti bagaimana perpektif pengarang mengenai situasi lingkungan hidup yang dideskripsikan dalam novel Partikel? Permasalahan lain yaitu bagaimana perilaku dan pemikiran manusia yang diwakili oleh tokoh Zarah di novel Partikel dalam memandang situasi lingkungannya?

\subsection{Tujuan}

Penelitian ini bertujuan untuk meninjau perspektif pengarang melalui tokoh Zarah mengenai relasi manusia dengan lingkungan hidup dalam Partikel. Di samping tujuan yang telah disebutkan, pendekatan ekokritis ini masih tergolong relatif baru sehingga akan memberikan perspektif yang berbeda dalam penelitian sastra Indonesia.

\section{KERANGKA TEORI}

\subsection{Sudut Pandang Pengarang}

Teknik cerita yaitu cara untuk menyusun sebuah cerita yang digunakan pengarang. Sukada (1987:74) menjelaskan ada dua jenis teknik cerita, yaitu metode bercerita (technique) dan sudut pandang (point of view). Penulis hanya menekankan pada aspek sudut pandang pengarang di dalam cerita.

Seorang pengarang memiliki otoritas untuk mengembangkan cerita. Pengarang bebas menggunakan suatu jenis sudut pandang atau mengombinasikannya dengan jenis sudut pandang yang lain. Sukada (1987:79) meringkas pendapat James L. Potter mengenai sudut pandang. Sudut pandang yang berbeda-beda adalah variasi dari sudut pandang dari beberapa jenis dasar. Hampir sebagian besar ditulis dari dua jenis sudut pandang, yaitu sudut pandang orang pertama dan sudut pandang orang ketiga.

Secara umum, efek yang diberikan dari dua jenis sudut pandang itu berbeda-beda. Sudut pandang orang ketiga memosisikan pembaca berada di luar cerita. Sudut pandang orang pertama melibatkan pengarang 
membaur dalam cerita. Pengarang seolah mengalami kejadian di dalam cerita.

Ada setidaknya dua alasan yang dikutip Sukada (1987:79) dari pernyataan Meredith dan Fitzgerald bahwa para pengarang lebih banyak menggunakan jenis sudut pandang pertama. Alasan pertama yaitu faktor kemudahan pemakaian bentuk gramatikal sehingga dapat berkomunikasi dengan tiap orang dalam kehidupan sehari-hari. Alasan kedua karena novel-novel dengan sudut padang pertama sebagian besar bersifat biografis.

Setiap jenis sudut pandang memiliki kelebihan dan kekurangan. Wellek dan Warren (1990:222) menyebutkan bahwa ada beberapa kekurangan dari jenis sudut pandang pertama. Dengan sudut pandang orang pertama, antara narator dan pengarang menjadi membaur. Jenis sudut pandang ini juga membuat pencerita kurang tajam terhadap tokoh-tokoh lainnya. Terlepas dari sisi kekurangan jenis ini, sudut pandang orang pertama berpotensi untuk membuat pembaca percaya terhadap cerita.

\subsection{Pendekatan Ekokritis}

Dalam artikel ini, penulis menggunakan pendekatan ekokritis. Ekokritisisme berfungsi untuk meninjau ulang peranan manusia dalam menyikapi alam dan lingkungannya melalui karya-karya sastra. Sebelum kemunculan kajian ini, ranah kesusasteraan masih diragukan atas kontribusinya terhadap krisis lingkungan. Kini, kajian ini menunjukkan bahwa bidang sastra dapat berperan penting dalam menghadapi tantangan zaman, yaitu krisis lingkungan hidup. Sebuah karya sastra mampu diselidiki sehingga menjadi sebuah hasil penelitian sastra yang peka terhadap masalah lingkungan hidup. Penelitian ini menggali kepekaan terhadap karya yang menampilkan problematika krisis lingkungan.

Dalam buku yang berjudul The Closing Circle, Barry Commoner (1974:16), seorang ahli ekologi, menjelaskan bahwa dalil pertama dari ekologi adalah "everything is connected to everything else (segala sesuatu terhubung dengan segala sesuatu yang lain)". Dalil ini memberi peluang bagi pemikiran-pemikiran yang mengaitkan konsep ekologi dengan bidang sastra. Karya sastra merupakan produk budaya. Kehadiran karya sastra yang berorientasi lingkungan hidup, menurut dalil tersebut, terhubung dengan pembacanya. Keterkaitan antara pembaca dan karya sastra, melalui kajian ekokritisisme, dapat memengaruhi hubungan manusia terhadap alamnya di dalam kehidupan nyata.

Pendekatan ekokritis bertujuan meningkatkan kesadaran manusia terhadap situasi bumi melalui karya sastra. Kesadaran berpikir secara ekologis ini penting untuk keberlangsungan hidup bumi ini. Sebagai sebuah pendekatan sastra, ekokritisisme menyediakan kerangka kerja atau mekanisme untuk menganalisis teks-teks budaya dan sastra yang secara langsung maupun tidak langsung terkait dengan masalah ekologi.

Ekokritisisme berbeda dari pendekatan sastra yang lain. Pada umumnya, teori sastra mengkaji hubungan antara pengarang, teks, dan dunia. Sebagian besar "dunia" yang dimaksud dalam studi sastra mengacu pada dunia sosial. Ekokritisisme tidak melihat "dunia" sebagai permasalahan sosial saja, tetapi juga permasalahan tentang alam semesta.

Krisis lingkungan hidup meninggalkan banyak pertanyaan untuk diselesaikan manusia. Di bidang sastra, kajian ekokritisisme berpangkal dari pertanyaan-pertanyaan seperti tentang; representasi alam dalam karya sastra, peran latar tempat dalam sebuah alur di dalam novel, nilai-nilai yang tersimpan di dalam novel yang sesuai dengan konsep-konsep ekologi, dan cara sastra dalam mengubah hubungan umat manusia dengan alamnya.

Seiring perkembangannya, ekokritisme dikembangkan dengan banyak cara. Walaupun demikian, ekokritisisme tetap berpegang pada satu premis, yaitu kebudayaan manusia dan alam saling memengaruhi. Premis ini bertolak dari premis yang diusulkan oleh Barry Commoner. Hukum pertama dari ekologi adalah segala sesuatu saling berhubungan (Commoner, 1979:18). Kaitan antara kajian sastra dan konsep ekologi adalah sastra tidak hanya mengambang di atas permukaan yang membicarakan masalah estetika, tetapi juga berperan dalam sebuah sistem global yang sangat kompleks bahwa energi dan ide itu saling memengaruhi.

\subsection{Metode Analisis}

Penelitian ini menggunakan kritik induktif. Kritik induktif adalah kritik sastra yang menguraikan bagian-bagian sastra berdasarkan fenomena-fenomena 
yang ada secara objektif. Melalui kritik ini, penelitian melihat teks secara objektif dan juga mengaitkan dengan konsep-konsep sesuai dengan pendekatan yang digunakan.

Metode yang digunakan dalam analisis ini adalah metode deskriptif-analitik. Metode ini diterapkan dengan cara mendeskripsikan fakta-fakta yang kemudian disusul dengan analisis (Ratna, 2007:53). Metode ini bermanfaat untuk menjelaskan bagianbagian yang diteliti dalam perumusan masalah.

\section{HASIL DAN PEMBAHASAN}

\subsection{Konsep-Konsep Dewi Lestari di Balik Penulisan Partikel}

Partikel memiliki banyak pertanyaan seperti tentang asal usul manusia dan relasi manusia dengan lingkungan. Pertanyaan-pertanyaan itu dituturkan melalui narasi tokoh Zarah yang memiliki kedekatan erat dengan alam. Menurut Dewi Lestari, pesan utamanya kurang lebih adalah untuk manusia bisa menggeser perspektif dari penguasa bumi menjadi pemelihara bumi.

Pesan dalam novel ini dilandasi oleh kerangka berpikir Dewi Lestari yang mengacu pada paradigma holistik. Ide untuk cerita Partikel dapat diperkuat dengan pernyataan Dewi Lestari tentang kedekatan manusia dengan alam, yaitu “...sejak eksistensi manusia dimulai, fase animisme, dinamisme, shamanisme, paganisme, dan juga kultur-kultur tradisional di seluruh dunia membuktikan adanya kedekatan manusia dengan alam, dengan cara membaca pertanda di langit, di bumi, dan seterusnya."

Sebelum memasuki proses menulis intensif selama 10-12 bulan, selama delapan tahun, Dewi Lestari melalui waktu dengan melakukan beberapa riset dan mengumpulkan informasi. Aktivitas Dewi Lestari yang cukup sibuk, membuatnya tidak punya banyak kesempatan untuk observasi lapangan secara langsung. Solusinya, ia mengandalkan teknik wawancara. Untuk mengetahui sebuah tempat, misalnya, ia bertanya sampai ke rasa udaranya bagaimana, lembap atau kering; air di sana bagaimana, jernih atau keruh; bagaimana rupa pepohonan dan tetumbuhan di sana, dan sebagainya.

Selain wawancara, Dewi Lestari melakukan riset pustaka. Ia lebih banyak membaca buku nonfiksi. Ia berkesempatan untuk berkenalan dengan Dr. Birute
Galdikas yang bukunya menjadi panduan bagi Dewi Lestari untuk menuliskan babak Tanjung Puting. Berikut adalah kutipan Dewi Lestari ketika diwawancarai Batam Pos tentang riset pustakanya.

\footnotetext{
"Satu buku bisa mencabangkan saya ke banyak buku lain, dan saya cerap saja semua informasinya di memori. Begitu tiba saatnya saya menulis, biasanya pengetahuan tersebut akan terseleksi, mana yang dituangkan dan mana yang tidak. Untuk Partikel, saking sudah lamanya saya mengumpulkan materi, saya harus membuat outline dulu. Berdasarkan panduan plot tersebut, maka dipilihlah informasi yang sekiranya menunjang cerita. Tapi, tentu pada pelaksanaannya proses tersebut berjalan organik dan banyak unsur spontanitas."
}

Riset pustaka yang dilakukan Dewi Lestari ini dibantu oleh hasil karya beberapa tokoh dari berbagai disipliner. Di dalam bagian "Dari Penulis" novel Partikel, Dewi Lestari (2012: 491-492) mengucapkan terima kasih pada tokoh-tokoh tersebut. Nama tokohtokoh tersebut tidak bisa ia sebutkan semuanya, antara lain adalah karya-karyanya Graham Hancock, Andrew Collins, Paul Stamets, Albert Hoffman, Daniel Pinchbek, Dolores Cannon, Barbara Hand Clow, Drunvalo Melchizedek, Bob Frissel, Greg Braden, Ralph Metzner, GordonWasson, Terrence McKenna, dan Albert Hoffman.

Teknik riset yang lain yaitu dengan cara menonton video. Dengan menonton video, Dewi Lestari tidak hanya membaca data, tapi melihat wujud visualnya. Salah satu yang paling berkesan selama riset Partikel adalah ketika Dewi Lestari bertemu dengan karyakaryanya Paul Stamets tentang fungi, dan juga menonton video-video presentasinya.

\subsection{Sudut Pandang Dewi Lestari sebagai Pengarang Novel Partikel}

Setiap pengarang memiliki otoritas atau kekuasaan untuk mengembangkan cerita sesuai kehendaknya. Untuk penyusunan sebuah cerita, pengarang memerlukan teknik bercerita. Teknik cerita ialah cara penyusunan suatu cerita yang digunakan oleh pengarang. Salah satu jenis teknik cerita yang dibahas dalam penelitian ini adalah sudut pandang pengarang (point of view).

Novel Partikel menggunakan sudut pandang orang pertama. Dewi Lestari memilih jenis sudut pandang orang pertama dengan menggunakan tokoh Zarah 
sebagai pencerita. Pengarang senantiasa menggunakan sudut pandang orang pertama sejak bagian awal hingga bagian akhir cerita. Dalam novel Partikel, Zarah adalah pencerita sekaligus tokoh yang berperan dalam setiap kejadian. Novel Partikel hanya mempunyai satu jenis sudut pandang. Seluruh penceritaan disampaikan melalui sudut pandang tokoh Zarah. Cerita disampaikan berdasarkan informasi yang diketahui Zarah. Sudut pandang tokoh-tokoh lain dalam novel disampaikan melalui kutipan-kutipan langsung dan deskripsi dari sudut pandang Zarah.

Salah satu efek dari jenis sudut pandang orang pertama adalah pengarang seolah mengalami kejadian di dalam cerita. Sudut pandang ini juga melibatkan pengarang membaur dalam cerita. Dalam kutipan yang tertera di bawah ini, ada kesan seolah pengarang adalah pencerita. Penggunaan sudut pandang orang pertama ini juga mendekatkan cerita kepada pembaca.

Lebih baik aku tenggelam di sini, Madidi, Taman Nasional Bolivia seluas 19 ribu kilometer persegi, berlokasikan di salah satu negara termiskin di Amerika Selatan, tapi bisa jadi yang terkaya dalam soal koleksi spesies flora fauna. Harta sejati. Fred Dunston, temanku dari Wildlife Conservation Society, meyakinkanku berkalikali bahwa Madidi mengerdilkan koleksi flora dan fauna Taman Nasional Manu, primadonanya Amazon, menjadi seperti Taman Safari Bogor. (Lestari, 2012:5)

Penggunaan sudut pandang orang pertama ini berpotensi untuk membuat pembaca percaya terhadap cerita yang disampaikan oleh pencerita. Hal ini dapat ditunjukkan melalui salah satu kutipan mengenai penjelasan.

Manusia sudah ber-evolusi terlalu jauh meninggalkan alam, membentengi dirinya sejak bayi dalam temboktembok semen dan lantai buatan. Kulit manusia terbiasa dibungkus rapat hingga alergi debu atau rentan pusing kalau kehujanan. Semua terlalu licin dan steril. Tidak heran kulit kami lubang-lubang di sini. Manusia telah ber-evolusi menjadi patung lilin. (Lestari, 2012:6)

Kutipan di atas, adalah pendapat pencerita mengenai evolusi manusia yang telah membuat manusia teralienasi dari alamnya. Dengan penjelasan mengenai pemikiran-pemikiran pencerita di dalam novel, hal ini menjadi nilai tambah dari sudut pandang orang pertama. Sudut pandang ini berpotensi membuat pembaca yakin dengan pendapat pencerita. Terlepas dari hal itu, penggunaan sudut pandang jenis ini menjadi alasan untuk mengatakan novel Partikel bersifat biografis.

Dalam Partikel, tokoh Zarah berperan sebagai narator. Peran Zarah sebagai tokoh sentral membuatnya terlibat dengan semua tokoh dan semua latar di dalam novel. Penggunaan sudut pandang pertama ini membantu pembaca untuk memahami jalan cerita, isi jalan pikiran Zarah, pendapat Zarah mengenai dirinya, tokoh lain, latar, suasana, dan kejadian. Hal yang paling penting, sudut pandang ini membantu pembaca dalam memahami jalan pikiran dan pendapat Zarah dan tokoh-tokoh lain terhadap lingkungan hidup.

\subsection{Perspektif Pengarang Mengenai Relasi Manusia dengan Lingkungan Hidup}

Pada dasarnya, selalu ada suatu gagasan yang ingin disampaikan oleh pengarang melalui cerita yang ditulisnya. Pemilihan sudut pandang penting untuk diperhatikan, dari sudut pandang yang digunakan pengarang, pembaca dapat mengetahui posisi pengarang di dalam cerita. Unsur-unsur struktur naratif tersebut menyokong gagasan pengarang dalam menjelaskan relasi manusia dengan lingkungan hidup.

Perspektif Dewi Lestari sebagai pengarang mengenai relasi manusia dengan lingkungan hidup tertuang dalam novel Partikel. Zarah, sebagai tokoh utama sekaligus narator dalam cerita, memiliki porsi lebih besar dalam menyimpan gagasan pengarang. Pemikiran-pemikiran Zarah tentang relasi antara manusia dan lingkungan hidup merupakan gagasan pengarang.

Krisis lingkungan hidup merupakan sebuah peringatan bahwa lingkungan hidup telah dalam bahaya. Commoner (1974:5) percaya hal ini terjadi karena rantai-rantai yang menghubungkan kehidupan satu dengan kehidupan lainnya terputus, dan di beberapa tempat telah berhenti. Sesuai dengan hukum alam, semua makhluk yang beradaptasi akan tetap hidup, sedangkan yang tidak dapat bertahan akan binasa. Commoner (1974:7) juga menganjurkan bahwa "If we are to, survive, we must understand why this collapse now threatens." Oleh karena itu, subbab ini penting untuk membahas relasi antara manusia dan lingkungan hidupnya.

Krisis lingkungan hidup terjadi karena relasi antara manusia dan lingkungan hidupnya tidak 
selaras. Menurut William Roth (dalam Commoner, 1974:2), krisis lingkungan hidup terjadi karena dua masalah, yang pertama adalah manusia, dan yang kedua adalah sifat manusia yang tidak pernah puas. Dalam hal ini, Anthony Storr (dalam Commoner, 1974:2) berpendapat bahwa "The sombre fact is that we are the cruelest and most ruthless species that has ever walked the earth." Di dalam novel Partikel, kalimat Storr senada dengan pernyataan Zarah yaitu "Kami adalah virus (Lestari, 2012:377)." Di peristiwa lain, Zarah juga mengungkapkan hal yang sama yaitu "manusia adalah penyakit terjahat bagi Bumi." (Lestari, 2012:422)

Arthuro Sandoval (dalam Commoner, 1974:2) berpendapat bahwa krisis alam terjadi karena manusia secara sistematis telah diajarkan untuk menjadi kejam oleh kemanusiaannya. Manusia tidak memiliki pemahaman bagaimana mencintai alam. Oleh karena itu, kegagalan ini mengakibatkan sungai-sungai teracun, udara tercemar, dan lahan hutan tergerus untuk dijadikan lahan pemukiman. Peristiwaperistiwa krisis lingkungan ini dapat ditemukan dalam Partikel. Di dalam cerita, hutan Kalimantan tidak lagi lebat, dan sungai Sekonyer sudah terkontaminasi limbah penambangan liar. Tidak hanya krisis pada sungai dan hutan, krisis lain yang ditampilkan dalam novel adalah kepunahan binatang, khususnya orangutan.

Untuk memahami malapetaka ini, manusia perlu memulai dengan melihat alam di lingkungan hidupnya secara lebih dekat. Sebagian besar manusia sulit untuk melihat alam secara dekat. Hal ini disebabkan manusia memiliki sifat yang paradoks. Dua posisi manusia ini dijelaskan oleh Barry Commoner (1974:8) di dalam kutipan di bawah ini.

Biologically, human beings participate in the environmental system as subsidiary parts of the whole. Yet, human society is designed to exploit the environment as a whole, to produce wealth. The paradoxical role we play in the natural environmental once participant and exploiterdistorts our perception of it.

Di satu sisi, manusia adalah pemelihara dan peserta yang saling mendukung proses kehidupan di bumi. Di sisi lain, manusia dirancang untuk mengeksploitasi lingkungan secara keseluruhan untuk menghasilkan kekayaan. Sifat paradoks manusia ini dibicarakan dalam sebuah percakapan antara Zarah dan tokoh lain yang bernama Simon. Di bawah ini adalah kutipan dari perkataan Simon kepada Zarah. Pada kutipan tersebut, pengarang menyadari bahwa manusia berpotensi untuk menjadi perusak atau penyembuh bumi.

"Kita bisa menjadi dua-duanya, Zarah," balas Pak Simon lembut. "Kita bisa membantu Bumi untuk pulih, atau kita bisa memperparah sakitnya. Bumi kita ini organisme hidup berintelegensi tinggi dan dia sadar atas semua yang kita lakukan padanya. Saya percaya itu." (Lestari, 2012:422)

Pada era perkembangan teknologi, Commoner (1974:5) mengatakan bahwa manusia semakin sulit memahami lingkungan hidupnya. Manusia telah membiasakan diri berpikir bahwa dirinya terpisah dari alam sehingga konsep rantai ekosistem sulit untuk diterapkan dalam kehidupan manusia modern. Pola pikir manusia kerap kali linier, tidak berbentuk lingkaran yang saling terkait. Cara pandang ini membawa pemahaman bahwa segala elemen di alam tidak saling berhubungan. Perkembangan teknologi telah mengubah pola pikir manusia dan menjauhkan manusia dari alam. Pemikiran ini juga telah dirasakan oleh Zarah. Zarah menganggap bahwa evolusi manusia telah membuat manusia meninggalkan alam. Kemajuan teknologi telah membuat manusia menciptakan lingkungan hidupnya sendiri yang membuat manusia menjadi makhluk yang lemah karena kemajuannya. Kutipan di bawah ini menujukkan pemikiran Zarah tentang evolusi manusia.

Manusia sudah ber-evolusi terlalu jauh meninggalkan alam, membentengi dirinya sejak bayi dalam temboktembok semen dan lantai buatan. Kulit manusia terbiasa dibungkus rapat hingga alergi debu atau rentan pusing kalau kehujanan. Semua terlalu licin dan steril. Tidak heran kulit kami lubang-lubang di sini. Manusia telah ber-evolusi menjadi patung lilin. (Lestari, 2012:6)

Untuk manusia yang hidup dikelilingi hasil produk kemajuan teknologi, perjuangan menyesuaikan diri dengan alam akan terasa lebih mudah. Mesin-mesin yang diciptakan manusia telah membawa manusia menjauhi habitat aslinya. Mereka menciptakan habitatnya sendiri. Mereka merasa tidak lagi langsung berhadapan dengan alam bebas. Jika panas, manusia 
dapat menyalakan pendingin ruangan. Jika cuaca terlalu dingin, manusia dapat menghidupkan pemanas ruangan. Kehidupan manusia menjadi lebih mudah dengan penemuan-penemuan teknologi tersebut.

Kemajuan teknologi telah membimbing manusia untuk percaya bahwa manusia telah membuat lingkungannya sendiri dan tidak lagi tergandtung pada apa yang disediakan langsung dari alam. Commoner (1974:8) melihat hal ini sebagai ilusi yang fatal karena manusia akan berpikir "that through our machines we have at last escaped from dependence on the natural environment."

Peradaban di era kemajuan teknologi sangat berbeda dengan peradaban primitif. Orang-orang dari peradaban primitif adalah masyarakat yang secara langsung sangat tergantung pada alam. Commoner menjelaskan dalam kutipan berikut ini.

Among primitive people, a person is seen as a dependent part of nature, a frail reed in a harsh world governed by natural laws that must be obeyed if be is to survive. Pressed by this need, primitive peoples can achieve a remarkable knowledge of their environment. (1974:8)

Unsur kehidupan masyarakat primitif terdapat dalam cerita. Pengarang nampak ingin membandingkan dua kutub yang saling berlawanan. Berikut ini adalah kutipan dalam novel ketika Zarah menggunakan obat tradisional dari suku Maasai, sebuah suku di Kenya, Afrika Selatan. Obat tradisional ini ternyata lebih mujarab daripada obatobatan yang diberikan pihak kedokteran.

Kuhentikan segala antibiotik pemberian klinik, memutuskan untuk percaya sepenuhnya pada obat dari Olubi. Dalam dua hari, semua gejalaku lenyap tanpa bekas. Begitu juga gatal-gatal dikulitku. Beruntus merah yang tadinya membengkak mulai mengempis dengan cepat, kemudian mongering, dan akhirnya rontok begitu saja. (Lestari, 2012:301)

Kutipan di atas menunjukkan bahwa masyarakat suku Maasai lebih memahami obat yang cocok untuk daerah mereka. Pengetahuan mereka boleh jadi melebihi ahli farmasi dalam hal ini. Suku Maasai masih hidup menurut hukum alam. Pengetahuan masyarakat suku Maasai didapat dari alam mereka. Dengan memahami alam, dengan relasi mereka dengan alam, segala kebutuhan yang mereka butuhkan terpenuhi. Dalam hal kesehatan, mereka mampu menangani sendiri melalui ramuan tradisional yang bahan-bahannya diambil dari alam.

Kemajuan teknologi cenderung membuat manusia mudah sombong dan menganggap spesies mereka lebih kuat. Firas, ayah Zarah, selalu mengajarkan Zarah bahwa manusia hidup bersama organisme lain oleh karena itu manusia tidak boleh sombong. Manusia tinggal di bumi yang memiliki beragam kehidupan. Pemikiran antroposentris akan membuat bumi hancur. Krisis lingkungan menuntut manusia untuk mengubah pola pikir manusia yang awalnya hanya mementingkan kepentingan pribadi menjadi pola pikir yang sadar akan keberadaan makhluk hidup lainnya.

Berbagai peristiwa di dalam cerita telah membuat Zarah memiliki pandangannya sendiri terhadap alam, bumi, dan lingkungan hidupnya. Di bawah ini adalah sejumlah kutipan yang mewakili pandangan bahwa pada hakikatnya manusia dan alam adalah satu bagian yang tak dapat dipisahkan. Pandangan inilah yang menjadi gagasan pengarang. Pengarang melalui tokoh Zarah menyampaikan gagasan-gagasannya tentang hubungan antara manusia dan alam. Melalui kutipan di bawah ini, dalam perspektif pengarang, krisis lingkungan hidup dapat diperbaiki dengan cara mengubah pola pikir yang menekankan bahwa alam dan manusia memiliki hubungan yang saling terkait dan tidak dapat dinegasikan satu dengan lainnya.

Detik itu, sebuah gelombang perasaan besar melandaku bagai air bah. Aku, hutan, dan awan bergerak dalam sebuah kesinambungan. Kami adalah satu. Batinku mulai gamang karena rasanya aku tidak lagi merasakan seorang bernama Zarah. Zarah telah lebur bersama arus ini. Arus, yang entah apa, tapi semua kehilangan identitas di dalamnya. Semua menjadi satu. (Lestari, 2012:146).

Mataku yang tadinya terpusat ke jalan mulai mampu melihat ke kiri-kanan, menjalin perkawanan dengan rimba bayang. Suara-suara aneh yang tadi mencekam mulai terdengar lebih bersahabat. Aku ini musang yang tahu jalan, pikirku lagi. Dan sekalipun kakiku kadang terseok dan tersuruk di setapak kecil ini, rasa takut itu tidak kembali lagi. Sesekali ada yang seperti mengintaiku dalam kegelapan itu, entah apa. Meski dalam hati, aku mencoba menyapa, kita adalah satu (Lestari, 2012:65).

[...] Dan orangutan adalah pengingatnya akan kemurnian manusia sebelum keluar dari Firdaus. Pada orangutan, kita dapat melihat sejatinya makhluk Firdaus yang tak pernah memutus hubungannya dengan kesatuan alam. (Lestari, 2012:228). 


\section{PENUTUP}

Situasi bumi yang sedang sekarat ini menginspirasi Dewi Lestari untuk menulis novel yang mengangkat tema tentang masalah bumi. Penulis melihat dominasi tema Partikel terletak pada krisis lingkungan hidup. Oleh karena itu, penulis menggunakan pendekatan ekokritis. Pendekatan tersebut digunakan untuk memahami perilaku dan pemikiran tokoh Zarah terhadap lingkungan hidupnya. Kesadaran berpikir secara ekologis penting untuk keberlangsungan hidup bumi ini. Hasil akhir dari penelitian ini yaitu untuk menguraikan perspektif pengarang melalui tokoh Zarah tentang gambaran relasi manusia dalam dengan lingkungan hidupnya.

Tokoh utama dalam cerita ini adalah Zarah Amala. Deskripsi fisik tokoh utama dalam cerita ini tidak terlalu kuat. Pengarang lebih menekankan pada penggambaran reaksi dan jalan pikiran Zarah. Dalam Partikel, Zarah berperan sebagai narator. Zarah adalah tokoh utama yang berkarakter kuat. Ia merupakan tokoh yang sangat peduli dengan alam dan bumi ini. Penulis menilai bahwa suara pengarang jelas terlihat dalam tokoh Zarah. Hal tersebut didukung dengan sumber literatur pengarang dalam penggarapan novel ini. Sebagian besar tokoh-tokoh di dalam Partikel dimunculkan dengan cara menggambarkan reaksi tokoh terhadap suatu kejadian, menggambarkan jalan pikiran tokoh dan menggambarkan keadaan sekitar tokoh.

Partikel memiliki isu-isu krisis lingkungan hidup. Krisis lingkungan yang ditampilkan pada novel adalah gambaran Dewi Lestari atas potret situasi hubungan manusia dengan lingkungannya. Dari hasil penelitian ini, penulis menemukan gagasan pengarang bahwa kerusakan bumi terjadi karena manusia tidak memahami alamnya. Manusia terasing dengan lingkungan hidupnya. Oleh karena itu, melalui Zarah, pengarang selalu menekankan bahwa manusia dan alam adalah satu kesatuan.

Partikel adalah karya sastra yang spesial karena novel ini membicarakan kondisi lingkungan hidup dan hubungan manusia dengan alam. Sejauh pengamatan penulis, belum banyak novel Indonesia yang memiliki kesadaran berlingkungan hidup seperti yang ditonjolkan Dewi Lestari. Keunggulan karya ini terletak pada kehadiran diskusi-diskusi tentang relasi antara manusia dan alam yang sangat jelas.

\section{CATATAN BELAKANG}

1) "According to the holistic paradigm, we are just cells in a big whole body that could be called the universe or God. The paradigm does not see sciences as separate entities. We see relations and connections in everything -- politics, the economy, ecology etc. The earth is sending a message. We are on the brink of extinction. Our thoughts about God are fragmented. If we thought we were just cells in one body, we would be more careful," (The Jakarta Post, Junaidi, 2006).

\section{DAFTAR PUSTAKA}

Basuki, Dian. “Al Gore, Perubahan dan Demokrasi yang Ditawan”, dalam Tempo, Edisi 8-14 April 2013.

Commoner, Barry. 1974. The Closing Circle. New York: Bantam Books.

Junaidi, A. 2 April 2006. “Dewi ‘Dee’ Lestari: Love, Spirituality, and Ecology”, The Jakarta Post. Diakses 17 April 2013, pukul 11.06 WIB. http://www.thejakartapost.com/news/2006/04/02/dewi-039dee039-lestarilove-spirituality-and-ecology.html

Lestari, Dewi. 2012. Supernova: Partikel. Yogyakarta: Bentang Pustaka.

Pradopo, Rachmat Djoko. 1994. Prinsip-prinsip Kritik Sastra. Yogyakarta: Gadjah Mada University Press.

Ramadhani, Alfi Yusrina. 2013. "Relasi antara Manusia dan Lingkungan Hidup dalam Novel Partikel Karya Dewi Lestari: Sebuah Kajian Ekokritisisme” (Skripsi). Depok: Fakultas Ilmu Pengetahuan Budaya Universitas Indonesia.

Rampan, Korrie Layun. 2000. "Wawasan Estetik Angkatan 2000 dalam Sastra Indonesia,” dalam Angkatan 2000 dalam Sastra Indonesia. Jakarta: Grasindo.

Ratna, Nyoman Kutha. 2007. Teori, Metode, dan Teknik Penelitian Sastra dari Strukturalisme hingga 
Alfi Yusrina Ramadhani: Perspektif Pengarang Mengenai Relasi ...

Postrukturalisme: Perspektif Wacana Naratif. Yogyakarta: Pustaka Pelajar.

Sukada, Made. 1987. Pembinaan Kritik Sastra Indonesia: Masalah Sistematika Analisis Struktur Fiksi. Bandung: PT Angkasa.

Wellek, Rene dan Austin Warren. 1989. Teori Kesusasteraan. Jakarta: PT Gramedia.

\section{Sumber Video}

Lestari, Dewi. 1 April 2012. Supernova - Cerita di Balik 4 Simbol. Diakses 20 April 2013, pukul 20.06 WIB. http://www.youtube.com/watch?v=Qf_cY3azuME

Ubud Writer Festival. 7 Oktober 2012. Five Minutes Alone-Dewi Lestari. Diakses 20 April 2013, pukul 20.08 WIB. http://www.youtube.com/watch?v=4RUSYrYSNcE

\section{Wawancara}

Lestari, Dewi. 7 April 2013. Wawancara melalui pos-el. 